\title{
RISALAH|
}

DOI: $10.24014 /$ jdr.v30i1.7268

\section{DAKWAH ZAKAT: MENYEBARKAN KEWAJIBAN BERZAKAT DI KALANGAN MASYARAKAT PETANI DI KEPULAUAN MERANTI}

\author{
Imron Rosidi ${ }^{1}$, Maswan Amin ${ }^{2}$ \\ ${ }^{1,2}$ Program Studi Manajemen Dakwah, Fakultas Dakwah dan Komunikasi, \\ Universitas Islam Negeri Sultan Syarif Kasim Riau \\ Email: imronrosidi@gmail.com
}

\begin{tabular}{l}
\hline Kata kunci \\
Zakat, BAZNAS, \\
Kepulauan Meranti, \\
Dakwah Zakat, \\
Kesalehan.
\end{tabular}

Keywords

Zakat (Alms), BAZNAS (National Alms Agency), Kepulauan Meranti, Zakat Dakwah, Religiosity.

\begin{abstract}
Abstrak
Zakat merupakan wacana penting dalam masyarakat Muslim sehingga ia sering kali dikaitkan dengan isu-isu penguatan ekonomi umat. Artikel ini bertujuan untuk menjelaskan bagaimana upaya yang dilakukan oleh Baznas (Badan Amil Zakat Nasional) Kepulauan Meranti dalam menggunakan manajemen dan instrumen modern untuk kegiatan menyebarkan kewajiban berzakat di kalangan masyarakat Muslim di Kepulauan Meranti. Menggunakan wawancara dan observasi untuk mendapatkan data, artikel ini menunjukkan bahwa Baznas sebagai lembaga zakat terus berupaya memperkuat dan mendorong kesadaran masyarakat Muslim berzakat sebagai simbol kesalehan. Artikel ini juga menunjukan bahwa lembaga-lembaga zakat yang semi-modern seperti Baznas Kepulauan Meranti melakukan negosiasi yang kompleks terkait kesadaran religius dan problem modernitas. Artikel ini juga menunjukan bagaimana menyebarkan pemahaman kewajiban berzakat sebagai proyek yang tak pernah selesai sebab nilai-nilai religiusitas acap kali membutuhkan elemen-elemen modernitas. Ruang kosong yang dibutuhkan lembaga-lembaga seperti Baznas ini adalah memperkuat penggunaan instrumen-instrumen modern dan implementasi manajemen modern dalam lembaga-lembaga tersebut.
\end{abstract}
Abstract
Zakat (alms) is an important discourse in a Muslim society so that it is often associated with the economic empowerment of the Ummah (Muslim community at large). This article aims to explain how the efforts made by National Alms Agency of Kepulauan Meranti to use modern instrument and management for disseminating the obligation to pay alms among Muslim people in Kepulauan Meranti. Using observation and interview to get data, BAZNAS has tried intensively to strengthen and improve the society's consciousness to pay Zakat as piety symbol. This article shows that semi-modern Zakat institution like BAZNAS Kepulauan Meranti conducts complicated negotiation related to religious awareness and problem of modernity. This article also shows how to spread the obligation to pay alms as a never-ending project because the 
values of religiosity often require elements of modernity. The empty space needed by institutions like BAZNAS is to strengthen the use of modern instruments and modern management implementation in these institutions.

\section{Pendahuluan}

Zakat, tak terbantahkan, merupakan isu utama dalam Islam. Sejumlah penelitian mendiskusikan urgensi zakat dalam merebut potensi sumber daya ekonomi yang tertinggal dalam masyarakat muslim, misalnya Farida (2016: 1-76), Marpuah (2016: 313-412) dan Ismail (2016: 629-680). Isu zakat dan problem ketertinggalan masyarakat muslim dalam aspek ekonomi merupakan imbas logis dari perkembangan globalisasi dan modernisasi yang sering kali menempatkan masyarakat muslim dalam posisi marginal (Hadiz, 2018). Marginalisasi masyarakat muslim dari kompetisi ekonomi nasional menjadi kekuatan di satu sisi dalam 'mobilisasi syariat', salah satunya melalui isu zakat dan potensi kekuatan ekonomi umat dan mobilisasi politik di sisi lain. Hal ini diperlihatkan oleh salah satu riset yang menarik yang dilakukan oleh Salim (2015). Melalui regulasi zakat yang dikeluarkan oleh pemerintah lokal, ia menjelaskan bagaimana zakat dijadikan alat mobilisasi ekonomi dan politik di Sumatera Barat.

Walaupun demikian, aspek zakat dan pemberdayaan ekonomi tetap menjadi favorit dalam riset-riset terkait zakat. Fokus riset terkait yang belum tersentuh adalah upaya-upaya yang dilakukan oleh lembaga-lembaga zakat yang tumbuh subur pasca-orde baru dalam menggiatkan dakwah untuk berzakat di kalangan masyarakat muslim. Lembaga-lembaga ini dalam skala kecil dan tingkat pengelolaan yang belum modern terus berupaya mendorong kesadaran masyarakat muslim berzakat, sebab membayar zakat merupakan simbol kesalehan utama dalam masyarakat muslim (Hassan, 2006: 59-60). Simbol kesalehan yang akan ditunjukkan dalam artikel ini menjadi wacana yang terus diperebutkan dalam masyarakat muslim dalam konteks membayar zakat. Kemudian, penelitian terkait zakat perlu memberikan fokus pada ikhtiar lembaga-lembaga zakat yang semi-modern untuk memahami negoisasi yang kompleks dan rumit yang mereka lakukan terkait kesadaran religius dan instrumen modern. Lembaga-lembaga ini seperti di daerah lain di Indonesia sering menghadapi kegagapan teknologi dan manejemen modern di tengah spirit religiusitas yang kuat.

Berbasis dua argumen di atas, artikel ini hendak menjelaskan cara yang dilakukan oleh lembaga Badan Amil Zakat Nasional Kepulauan Meranti dalam menyebarkan kewajiban berzakat di kalangan masyarakat semi-modern di Kepulauan Meranti. Temuan artikel ini berguna untuk melihat bagaimana menyebarkan pemahaman kewajiban berzakat sebagai proyek yang tak pernah selesai sebab nilai-nilai religiusitas acap kali membutuhkan instrumen modern. Ruang kosong yang dibutuhkan lembaga-lembaga religius ini adalah, alihalih meningkatkan paham keagamaan mereka yang sudah mapan, memperkuat basis pemahaman dan implementasi instrumen modernitas seperti manajemen dan penggunaan media modern.

\section{Metode}

Metode yang digunakan dalam artikel ini berbasis pendekatan sosiologis yang menegasikan model-model penelitian berbasis doktrin. Dengan demikian metode deskriptif kualitatif merupakan metode yang dianggap tepat untuk menjelaskan fakta-fakta 'apa adanya' dalam proses berdakwah kewajiban berzakat yang dilakukan oleh BAZNAS Kepulauan Meranti. Data dikumpulkan melalui observasi, wawancara, dan dokumentasi. Karena berbasis 
pendekatan sosiologis, temuan yang dihasilkan tidak menjanjikan untuk berbanding lurus dengan teks-teks keagamaan yang dianggap otoritatif dalam masyarakat muslim.

Informan dalam artikel ini adalah 8 orang yang dipilih berdasarkan teknik purposive sampling. Teknik purposive sampling adalah pengambilan sampel atau informan berdasarkan pertimbangan tertentu. Pertimbangan yang dimaksud misalnya orang tersebut yang dianggap paling tahu tentang apa yang kita harapkan atau mungkin dia sebagai penguasa sehingga akan memudahkan peneliti menemukan fakta yang diharapkan (Sugiyono: 2015). Lima informan dipilih dari pengurus Badan Amil Zakat Nasional (BAZNAS) Kabupaten Kepulauan Meranti yaitu Ketua BAZNAS Kabupaten Kepulauan Meranti, Wakil Ketua I Bidang Pengumpulan dan Pengembangan BAZNAS Kabupaten Kepulauan Meranti, Ketua Bidang Pengumpulan dan Pengembangan BAZNAS Kabupaten Kepulauan Meranti, Ketua UPZ Kecamatan Rangsang Barat, Sekretaris UPZ Kecamatan Rangsang Barat serta 3 informan diambil dari Petani Tanaman Padi Kecamatan Rangsang Barat Kepulauan Meranti.

\section{Hasil dan Pembahasan}

Artikel ini, berbasis hasil wawancara dan observasi, menemukan bahwa zakat merupakan fenomena religius sekaligus sekuler. Ia dianggap sebagai fenomena religius karena sejumlah doktrin dalam agama Islam menyebutkan kewajiban berzakat. Alquran setidaknya menyebut sebanyak 82 kali yang seringkali dikaitkan dengan kewajiban melakukan salat (Ali, 1988: 9 \& Salim, 2015: 79). Ia dianggap fenomena sekuler karena dalam rangka menyukseskan kewajiban tersebut memerlukan instrumen-instrumen modern yang sifatnya duniawi. Dengan demikian pembahasan artikel ini akan melihat proses negosiasi dua fenomena tersebut dalam konteks lokal di Kepulauan Meranti.

\section{BAZNAS dalam Masyarakat Muslim di Kepulauan Meranti}

Sebagian besar masyarakat muslim di Kepulauan Meranti, sebagaimana di daerah lain di Indonesia, berprofesi sebagai petani tradisional. Basis pendapatan masyarakat adalah sumber daya alam. Tidak heran jika Indonesia dikenal sebagai negara agraris. Negara ini memiliki potensi yang besar dari sektor pertanian. Dengan didukung iklim, kesuburan tanah, hutan, dan sumber air, mayoritas penduduk Indonesia menggantungkan profesi utamanya sebagai petani. Dari segi sumber pendapatan, Kepulauan Meranti memiliki potensi sumber daya alam yang beragam baik sektor migas maupun nonmigas. Sektor migas berasal dari minyak bumi dan gas alam, sedangkan pendapatan dari sektor nonmigas berasal dari perkebunan sagu, padi, kopi, karet, pinang, dan lain sebagainya. Salah satu kecamatan di Kepulaun Meranti yang memiliki sumber pendapatan padi melimpah adalah Kecamatan Rangsang Barat. Tidak heran jika pemerintah Kabupaten Kepulauan Meranti menetapkan Kecamatan Rangsang Barat sebagai daerah lumbung padi. Data statistik menunjukkan luas tanaman padi yang ada di Kecamatan Rangsang Barat sebanyak 1872 hektar dan menghasilkan 3,7 ton gabah kering per hektar.

Sebagai penghasil padi yang cukup besar, BAZNAS Kepulauan Meranti memfokuskan dakwah zakat padi di Kecamatan Rangsang Barat sebagai program utama. Kecamatan Rangsang Barat merupakan salah satu kecamatan yang ada di Kabupaten Kepulauan Meranti, terdiri dari 12 Desa yaitu, Desa Segomeng, Desa, Bantar, Desa Anak Setatah, Desa Lemang, Desa Bokor, Desa Sungain Cina, Desa Melai, Desa Telaga Baru, Desa Bina Maju, Desa Sialang Pasung, Desa Permai, dan Desa Mekar Baru. Namun yang memiliki lahan pertanian padi hanya enam Desa, yaitu, Desa Mekar Baru, Desa, Bina Maju, Desa Segomeng, Desa Melai, Desa Anak Setatah, dan Desa Sungai Cina. Bahasa dakwah dalam konteks ini lebih merujuk pada upaya menyebarkan pemahaman kewajiban berzakat melalui insrumen-instrumen modern. 
Melihat konteks pendapatan yang besar dari sektor pertanian padi, BAZNAS Kepulauan Meranti kemudian menyusun program terkait dengan upaya menyebarkan pemahaman tentang pentingnya membayar zakat padi bagi kalangan Muslim. Upaya yang dilakukan BAZNAS tersebut tidak lepas dari sejarah awal pendirian BAZNAS Kepulauan Meranti melalui Surat Keputusan Bupati Kepulauan Meranti No. 76 A tahun 2011 yang bertujuan mengumpulkan dana zakat bagi pengembangan ekonomi umat.

Tujuan formal BAZNAS Kabupaten Kepulauan Meranti adalah untuk mencapai daya guna, hasil guna, dan akuntabilitas dalam pengelolaan dana Zakat, Infak dan Sedekah (ZIS). Hal ini tentu terkait dengan upaya untuk meningkatkan peran serta umat Islam kabupaten Kepulauan Meranti dalam rangka pembangunan manusia seutuhnya melalui pengelolaan dana ZIS.

Sebelum BAZNAS Kabupaten Kepulauan Meranti didirikan, pengumpulan dan pengelolaan dana ZIS dikelola oleh Badan Amil Zakat (BAZ) Kecamatan Tebing Tinggi, yang pada masa itu dipimpin oleh $\mathrm{H}$. A. Karim, Z, SH. BAZ Kecamatan Tebing Tinggi merupakan unit dari BAZ Kabupaten Bengkalis yang dibentuk sebelum pemekaran Kabupaten Kepulauan Meranti.

Secara yuridis, pendirian Badan Amil Zakat Nasional Kabupaten Kepulauan Meranti merujuk pada Undang-undang Pemerintah Republik Indonesia, yaitu; Undang-undang Nomor 38 Tahun 1999 tentang Pengelolaan Zakat (Lembaran Negara Republik Indonesia Tahun 1999 Nomor 164, Tambahan Lembaran Negara Republik Indonesia Nomor 3885), Surat Keputusan Menteri Agama RI Nomor 373 Tahun 2003 tentang Pelaksanaan Undang-undang Nomor 38 Tahun 1999 tanggal 18 Juli 2003, Keputusan Direktur Jenderal Bimbingan Masyarakat Islam dan Urusan Haji Nomor D/291 Tahun 2000 tentang Pedoman Teknis Pengelolaan Zakat, Peraturan Daerah Provinsi Riau Nomor 2 Tahun 2009 Tentang Pengelolaan Zakat, Undang-undang Nomor 23 tahun 2011 tentang Pengelolaan Zakat, yang disahkan oleh DPR RI pada tanggal 27 Oktober 2011 yang merupakan hasil amandemen pengganti Undang-undang Nomor 38 tahun 1999 karena tidak sesuai dengan perkembangan dan kebutuhan hukum dalam masyarakat, Surat Keputusan Bupati Kepulauan Meranti Nomor: 76 Tahun 2011 Tanggal 21 Maret 2011 tentang Pembentukan Pengurus Badan Amil Zakat Nasional (BAZNAS) Kabupaten Kepulauan Meranti, Surat Keputusan Bupati Kepulauan Meranti Nomor: 299 Tahun 2015 Tanggal 23 Juni 2015 tentang Penunjukan Pelaksanaan Tugas Pengurus Badan Amil Zakat Nasional (BAZNAS) Kabupaten Kepulauan Meranti, Peraturan Daerah Kabupaten Kepulauan Meranti No 05 Tahun 2015 tentang zakat.

Aneka ragam peraturan yang terkait zakat di atas menunjukan dan mengindikasikan manajemen atau pengelolaan zakat di Indonesia, khususnya di Kepulauan Meranti tidak kohesif dan solid. Ragam peraturan juga menunjukkan dimensi tarik-menarik perizinan yang memungkinkan setiap aktor sosial dalam aspek terkait mengeruk keuntungan, dan zakat pada hakikatnya tidak bebas dari aspek tersebut.

BAZNAS Kabupaten Kepulauan Meranti memiliki beberapa program penting sebagai berikut:

1. Meranti Agamis: program ini terkait dengan pengiriman dai di daerah-daerah terisolir untuk pembinaan pendidikan agama khususnya para mualaf (Desa Selat Akar, Kepau Baru, Sonde, Beting dan Sesap) dengan jumlah persentase $15 \%$ dari zakat yang terhimpun.

2. Meranti Cemerlang: program ini fokus pada pengadaan beasiswa bagi kaum duafa di setiap sekolah yang sudah membentuk UPZ dan menghimpun dana zakat, dengan jumlah persentase $15 \%$ dari zakat yang terhimpun.

3. Meranti Sehat: program ini dibuat untuk membantu meringankan biaya transportasi masyarakat miskin dalam perobatan khususnya bagi pasien. Program 
ini menyediakan ambulans laut dan ambulans darat bagi mereka yang harus dirujuk di luar wilayah kabupaten kepulauan meranti melalui mekanisme yang telah ditentukan dengan jumlah persentase $20 \%$ dari zakat yang terhimpun.

4. Meranti Produktif: program ini dilakukan dengan memberikan bantuan modal usaha mikro tanpa agunan dan bunga bagi mereka yang tidak mampu dan berkeinginan untuk berwirausaha, serta memberikan pendampingan dan pengawasan yang bekerja sama dengan Perbankan syariah, dengan jumlah persentase $20 \%$ dari zakat yang terhimpun.

5. Meranti Peduli: program ini dilakukan dengan memberikan bantuan kepada mustahik yang mendapatkan musibah seperti korban kebakaran, banjir, dan musafir serta rumah yang sudah tidak layak huni (sangat darurat), dengan jumlah persentase $15 \%$ dari zakat yang terhimpun.

6. Meranti Konsumtif: program ini dilaksanakan dengan memberikan bantuan kepada kaum duafa khususnya para orang tua jompo yang bersifat konsumtif yang biasanya disalurkan menjelang bulan suci Ramadan, dengan jumlah persentase $15 \%$ dari zakat yang terhimpun.

\section{Prosedur BAZNAS Kabupaten Kepulauan Meranti dalam Pengumpulan Zakat}

Secara lengkap prosedur yang dilakukan oleh Baznas Kepulauan Meranti terkait upaya untuk mengumpulkan zakat adalah sebagai berikut:

1. Layanan penerimaan titipan zakat para muzaki setiap hari pada jam kerja.

2. Layanan penyaluran dan pengelolaan zakat mengacu pada aturan Alquran dan hadis.

3. Layanan informasi dan konsultasi BAZNAS pada tingkat kecamatan se-kabupaten Kepulauan Meranti.

4. Pendataan dan sensus bagi masyarakat yang kurang mampu khususnya para mustahik melibatkan kepala desa, camat, dinas sosial serta dinas- dinas terkait sebagai mitra kerja.

5. Layanan program jemput zakat untuk mempermudah para muzaki pada setiap instansi yang sudah membentuk UPZ-UPZ.

6. Memberikan pelaporan dan pertanggungjawaban terhadap semua kegiatan.

7. Teknik pengumpulan:

a. UPZ antar ke BAZNAS

b. BAZNAS menjemput ke UPZ

c. Muzakki antar ke BAZNAS

d. BAZNAS menjemput ke muzaki

e. Melalui rekening BAZNAS

8. Sasaran penyaluran zakat dan infak

a. Zakat : fakir, miskin, fisabililah, ibnu sabil, gharimin, mualaf.

b. Infak : Pembangunan fasilitas umat seperti masjid, madrasah, dan pengembangan pendidikan dakwah.

\section{Dakwah Zakat Padi}

Dalam istilah modern, dakwah zakat padi berarti upaya menyebarkan atau mensosialisaikan urgensi membayar zakat dari pendapatan padi bagi petani-petani muslim. Dalam upaya memaksimalkan pengumpulan zakat, berdasarkan Peraturan Badan Amil Zakat Nomor 2 Tahun 2016 tentang Pembentukan dan Tata Kerja Unit Pengumpul Zakat, maka 
dibentuklah Unit Pengumpul Zakat atau disingkat dengan UPZ di setiap kecamatan di Kabupaten Kepulauan Meranti, termasuk di Kecamatan Rangsang Barat.

Potensi zakat padi yang ada di Kecamatan Rangsang Barat Kepulauan Meranti cukup besar yang mendorong BAZNAS Kepulauan Meranti berupaya menyebarkan pemahaman para petani padi untuk membayar zakat. Cara yang ditempuh oleh BAZNAS, pertama, adalah membentuk organisasi perpanjangan tangan dari BAZNAS berupa UPZ di level Kecamatan di Kabupaten Kepulauan Meranti. Sunarto, Ketua BAZNAS Kabupaten Kepulauan Meranti menuturkan:

"Unit Pengumpul Zakat (UPZ) merupakan perpanjangan tangan dari BAZNAS Kabupaten Kepulauan Meranti dalam melaksanakan pengelolaan zakat, mulai dari tahap sosialisasi, pengumpulan, dan pendistribusian. begitu juga dalam hal sosialisasi zakat padi ini, kami juga selalu berkoordinasi dan menjalin komunikasi yang baik dengan pengurus UPZ Rangsang Barat,”.

Pendistribusian otoritas melalui pembentukan UPZ tersebut dimungkinkan untuk memudahkan pelaksanaan dan pengelolaan zakat sebagai wujud dari sistem manajemen modern. Perwujudan dari manajemen modern tersebut sejalan dengan yang disampaikan oleh Sodikin Sekretaris UPZ Rangsang Barat bahwa "Kami (Pengurus UPZ Rangsang Barat) selalu berkoordinasi dengan pengurus BAZNAS Kabupaten Kepulauan Meranti dalam melaksanakan sosialisasi zakat ini, baik sosialisasi zakat secara umum maupun sosialisasi zakat padi secara khusus".

Implementasi dari manajemen modern juga terlihat dari upaya BAZNAS Kabupaten Kepulauan Meranti yang menyusun Standar Ukuran Zakat Pertanian, khususnya zakat padi. Sebagaimana hasil wawancara dengan Sunarto Ketua BAZNAS Kabupaten Kepulauan Meranti menuturkan bahwa:

"Kami menyusun standar ukuran zakat pertanian padi ini mengikuti dengan pemahaman masyarakat setempat, di mana kita ketahui bahwasanya nisab atau ukuran zakat padi itu adalah $653 \mathrm{~kg}$, namun petani padi setempat tidak paham perhitungan seperti itu, yang mereka paham adalah dengan hitungan TIM. Sedangkan itu tidak sesuai dengan syariat Islam. Oleh karena itu, kami selaku amil zakat meluruskan dengan tetap hitungan TIM namun disesuaikan dengan ukuran nisab yang telah ditetapkan syariat Islam."

Standar ukuran zakat pertanian padi yang dibuat BAZNAS Kabupaten Kepulauan Meranti adalah sebagai berikut: nisab padi/gabah sebanyak $653 \mathrm{~kg}$ padi/gabah (setiap panen). $653 \mathrm{~kg}$ padi/gabah dengan harga Rp5000*/kg (653x5000=Rp3.265.000).

Cara menghitung menjadi hitungan per TIM: 1 TIM padi /gabah dibagi $12 \mathrm{~kg}$ padi/gabah** (sesuai dengan jenis dan berat padi/gabah). $653 \mathrm{~kg}$ padi/gabah dibagi $12 \mathrm{~kg}$ padi/gabah $=55 \mathrm{TIM}$ padi/gabah sehingga yang wajib dikeluarkan zakatnya: $5 \%=2,75 \mathrm{TIM}$ digenapkan menjadi 3 TIM atau diuangkan menjadi Rp180.000. 10\% = 5,5 TIM digenapkan menjadi 6 TIM atau diuangkan menjadi Rp360.000.

Nisab beras sebanyak $524 \mathrm{~kg}$ beras (setiap panen). $524 \mathrm{~kg}$ beras dengan harga $\mathrm{Rp} 10.000^{*} / \mathrm{kg}(524 \times 10.000=\mathrm{Rp} 5.240 .000)$. Cara menghitung menjadi hitungan per TIM: 1 TIM beras $=15 \mathrm{~kg}$ beras** (sesuai dengan jenis dan berat beras). $524 \mathrm{~kg}$ beras dibagi $15 \mathrm{~kg}$ beras $=35$ TIM beras sehingga yang wajib dikeluarkan zakat: 5\% = 1,75 TIM digenapkan menjadi 2 TIM atau diuangkan menjadi Rp300.000. 10\% = 3,5 TIM digenapkan menjadi 4 TIM atau diuangkan menjadi Rp600.000.

Dilihat dari aturan yang dibuat oleh BAZNAS terkait pembayaran zakat padi atau beras di atas, terdapat proses lokalisasi zakat yang dimungkinkan untuk memudahkan 
masyarakat muslim dalam memahami kewajiban membayar zakat yang dimaksud. Istilahistilah lokal yang sering digunakan muslim di daerah ini disebut seperti TIM. Istilah ini bukan merujuk pada 'team' atau kelompok, namun ia merujuk pada 'tempat atau wadah besar' yang terbuat dari kaleng.

Hal seperti di atas dilakukan karena, menurut Sunarto, Ketua BAZNAS Kabupaten Kepulauan Meranti:

"Sosialisasi zakat itu tidak mudah seperti membalikkan telapak tangan, butuh metode yang pas dan juga yang kita hadapi itu masyarakat yang memiliki latar belakang yang berbeda, baik dari segi pendidikan, ekonomi, dan sosial. Jangankan petani, orang yang pintar saja tak langsung paham, makanya perlu metode sosialisasi yang tepat agar pesan zakat dapat tersampaikan".

Tidak heran jika model pendekatan religius juga dilakukan oleh BAZNAS Kabupaten Kepulauan Meranti dalam mensosialisasikan atau dakwah zakat padi. Ceramah misalnya dilakukan oleh BAZNAS untuk mendorong pemahaman masyarakat muslim tentang zakat di satu sisi sekaligus mendistribusikan otoritas kelembagaan BAZNAS ke sosok pendakwah.

Berdasarkan wawancara dengan Abdul Rauf, Ketua UPZ Rangsang Barat, menuturkan bahwa:

"Metode ceramah merupakan salah satu metode yang kami gunakan dalam sosialisasi zakat padi ini. Sifatnya seperti pengajian atau majelis taklim, penceramahnya adalah saya sendiri dan tidak menutup kemungkinan juga penceramahnya dari luar, seperti dari pengurus BAZNAS Kabupaten Kepulauan Meranti." bahwa:

Senada dengan yang disampaikan oleh Sodikin, Sekretaris UPZ Rangsang Barat,

"UPZ Rangsang Barat saat ini memang telah melakukan sosialisasi zakat padi melalui metode ceramah, penceramahnya sendiri adalah ketua UPZ kecamatan Rangsang Barat yaitu Ustaz Rauf, tapi bisa juga penceramahnya dari luar sesuai kesepakatan pengurus UPZ lah, yang penting penceramahnya pahamlah dengan materi zakat padi ini”.

Sunarto, Ketua BAZNAS Kabupaten Kepulauan Meranti, mengatakan bahwa: "UPZ Rangsang Barat dalam pelaksanaan sosialisasi zakat padi telah melaksanakan metode ceramah ini, yang penceramahnya langsung oleh ustaz Rauf yang sekaligus Ketua UPZ Rangsang Barat, beliau sangat pahamlah tentang materi zakat padi ini".

Menggunakan model pendekatan religius seperti ceramah dianggap efektif jika ia menggabungkan instrumen dan manajemen modern. Hal ini dilakukan misalnya melalui perencanaan dengan pemilihan waktu pelaksanaan, di mana tempat sosialisasinya dan bagaimana proses dalam metode ceramah ini dilaksanakan. Hal ini dilakukan dengan harapan tujuan dari dakwah atau sosialisasi zakat ini dapat berjalan dengan baik. Hal ini sebagaimana diungkapkan oleh Abdul Rauf, Ketua UPZ Rangsang Barat bahwa: "Metode ceramah ini efektifnya kami laksanakan di bulan puasa ketika kegiatan Safari Ramadan, jadi, kami mengunjungi masjid-masjid setiap desa yang memiliki lahan pertanian padi”.

Hal yang sama diungkapkan oleh Sodikin sekretaris UPZ Rangsang Barat bahwa:

"Iya, memang benar, kami telah melaksanakan metode ceramah ini ketika Safari

Ramadan. Waktunya bergantung kondisi sesuai kesepakatan pengurus, contohnya malam pertama Ramadan ceramah di Desa Mekar Baru, selang beberapa hari pindah ceramah ke Desa Bina Maju dan seterusnya sampai ke enam desa yang memiliki lahan padi tersosialisasikan." 
Syafarudin, petani padi dan juga sekaligus Ketua Kelompok Tani Nelayan Andalan Desa Mekar Baru, mengatakan bahwa "Pengurus UPZ Rangsang Barat biasanya bulan puasa ceramah di masjid di Desa kami”. Bulan Ramadan dianggap waktu yang tepat untuk berdakwah tentang zakat karena pada bulan ini spirit religiusitas masyarakat muslim berada dalam titik yang paling kuat. Sebagian besar masyarakat muslim melakukan ritual puasa dan ritual sunah untuk meningkatkan kesalehan mereka. Simbol-simbol agama Islam juga muncul semarak di ruang publik pada bulan ini sehingga istilah-istilah agama atau doktrin agama akan mudah diserap pada waktu ini. Abdul Rauf, Ketua UPZ Rangsang Barat menjelaskan bahwa:

"Metode ini kami laksanakan setelah salat tarawih dan witir, sebelumnya kami koordinasi dahulu dengan pengurus masjid setempat, bahwasanya kami ingin mengadakan ceramah di masjid tersebut. Dan meminta pengurus masjid untuk menginformasikan kepada jamaah, agar jamaah tidak langsung pulang setelah salat witir".

Selain momentum bulan Ramadan, ceramah juga dilakukan pada saat peringatan hari besar keagamaan Islam. Sodikin, Sekretaris UPZ Rangsang Barat mengatakan bahwa:

"Selain itu juga, metode ceramah ini kami laksanakan juga pada Peringatan Hari Besar Islam (PHBI) seperti peringatan Maulid Nabi Muhammad saw., Isra Mikraj, peringatan tahun baru Islam dan lain sebagainya. Namun ini hanya kita sisipkan di acara tersebut, Dan tentunya tidak membutuhkan waktu yang terlalu lama."

Model pemanfaatan kegiatan keagamaan tertentu merupakan implementasi dari manajemen modern yang bertujuan untuk efektivitas dan efisiensi. Hal ini karena pendekatan seperti ini tidak membutuhkan tenaga untuk mengumpulkan masyarakat dalam satu tempat.

Lebih jauh, Abdul Rauf, Ketua UPZ Rangsang Barat menjelaskan bahwa:

"Metode ceramah ini kami laksanakan seperti majelis taklim atau pengajian pada umumnya, penceramah memiliki sekitar 30-40 menit untuk menyampaikan materi ketika bulan Ramadan, durasi waktunya memang tidak begitu lama, karena kita juga mempertimbangkan kondisi masyarakat ketika bulan puasa, tentunya sudah lelah, siangnya berpuasa, dan malamnya tentu butuh istirahat yang cukup. Tapi kalau sosialisasinya ketika acara peringatan hari besar Islam cuma sekitar 20 menit lah, karena sifatnya hanya selingan dalam acara tersebut".

Istilah 'selingan' dalam pernyataan di atas diasumsikan seperti 'iklan' dalam dunia pertelevisian. Sistem seperti ini mengadopsi 'marketing' dalam manajemen modern. Produk marketing yang ditawarkan adalah sosialisasi zakat padi yang dikemas sedemikian rupa. Isi dakwah atau sosialisasi disesuaikan juga dengan kebutuhan petani padi. Oleh karena itu, sebagaimana yang disampaikan oleh Abdul Rauf, Ketua UPZ Rangsang Barat bahwa:

"Materi yang kami sampaikan sesuai dengan kebutuhan petani padii seperti menjelaskan berapa ukuran wajib zakat padi, kemudian kapan zakat padi dikeluarkan, berapa zakat padi yang harus dikeluarkan, serta ancaman bagi orang yang tidak mau membayar zakat, pentingnya berzakat melalui UPZ dan lain sebagainya. Pokoknya berkenaan zakat padilah".

Dari segi intensitas, metode ceramah seperti ini sering dilakukan oleh UPZ Rangsang Barat dalam mensosialisasikan zakat padi ini, seperti yang dinyatakan oleh Sodikin sekretaris UPZ Rangsang Barat bahwa "Metode yang selalu kami laksanakan dalam sosialisasi zakat padi adalah metode ceramah karena metode ini sangat mudah untuk dilaksanakan". Di waktu 
yang berbeda, Muslim, Ketua Bidang Pengumpulan dan Pengembangan BAZNAS Kabupaten Kepulauan Meranti juga menuturkan "Metode ceramah ini sangat mudah untuk dilaksanakan dan tidak begitu rumit, dan juga pesertanya ramai".

Untuk lebih jelasnya, tabel berikut merupakan daftar pelaksanaan zakat padi melalui ceramah di kecamatan Rangsang Barat:

Table 5.1 Sosialisasi Zakat Padi melalui ceramah

\begin{tabular}{|c|c|c|c|c|c|}
\hline No & Hari/Tanggal & Jam & Tempat & Materi & Pemateri \\
\hline 1 & $\begin{array}{l}\text { Jum'at/18 Mei } \\
2018(2 \text { Ramadan } \\
1439 \mathrm{H})\end{array}$ & 21.30 & $\begin{array}{c}\text { Masjid } \\
\text { Mekar Baru }\end{array}$ & $\begin{array}{l}\text { Pelaksanaan } \\
\text { zakat padi }\end{array}$ & $\begin{array}{l}\text { Abdul Rauf, } \\
\text { M.Pd.I (Ketua } \\
\text { UPZ Rangsang } \\
\text { Barat) }\end{array}$ \\
\hline 2 & $\begin{array}{l}\text { Rabu/23 Mei } 2018 \\
\text { (7 Ramadan } 1439 \\
\text { H) }\end{array}$ & 21.30 & $\begin{array}{c}\text { Masjid Bina } \\
\text { Maju }\end{array}$ & $\begin{array}{l}\text { Pelaksanaan } \\
\text { zakat padi }\end{array}$ & $\begin{array}{l}\text { Khozin,MA } \\
\text { (Sekretaris } \\
\text { BAZNAS } \\
\text { Meranti) } \\
\end{array}$ \\
\hline 3 & $\begin{array}{l}\text { Senin/28 Mei } 2018 \\
\text { (12 Ramadan } 1439 \\
\text { H) }\end{array}$ & 21.30 & $\begin{array}{l}\text { Masjid } \\
\text { Desa } \\
\text { Segomeng }\end{array}$ & $\begin{array}{l}\text { Pelaksanaan } \\
\text { zakat padi }\end{array}$ & $\begin{array}{l}\text { Sunarto, S.Ag } \\
\text { (Ketua } \\
\text { BAZNAS } \\
\text { Meranti) }\end{array}$ \\
\hline 4 & $\begin{array}{l}\text { Sabtu/ } 2 \text { Juni } 2018 \\
\text { (17 Ramadan } 1439 \\
\text { H) }\end{array}$ & 21.30 & $\begin{array}{c}\text { Masjid } \\
\text { Desa Melai }\end{array}$ & $\begin{array}{l}\text { Pelaksanaan } \\
\text { zakat padi }\end{array}$ & $\begin{array}{l}\text { Mustafa, S.Ag, } \\
\text { MM (Wakil } \\
\text { ketua I } \\
\text { BAZNAS } \\
\text { Meranti) } \\
\end{array}$ \\
\hline 5 & $\begin{array}{l}\text { Sabtu/14 April } \\
2018 \text { (Isra Mikraj } \\
1439 \text { H) }\end{array}$ & 22.00 & $\begin{array}{l}\text { Masjid } \\
\text { Desa Anak } \\
\text { Setatah }\end{array}$ & $\begin{array}{l}\text { Pelaksanaan } \\
\text { zakat padi }\end{array}$ & $\begin{array}{l}\text { Abdul Rauf, } \\
\text { M.Pd.I (Ketua } \\
\text { UPZ Rangsang } \\
\text { Barat) }\end{array}$ \\
\hline
\end{tabular}

Abdul Aziz Wahab (2012: 88) mengatakan bahwa metode ceramah merupakan metode yang mudah untuk dilakukan, dalam arti bahwa ia tidak memerlukan persiapan yang rumit. Selain tidak rumit, cara ini bisa dilakukan dalam waktu yang tidak lama dengan audiens yang cukup banyak (Maryatin, 2014). Walaupun demikian, cara ini tetaplah memiliki kekurangan sebagaimana dikemukana oleh Wahab (2012) dan Fathurrahman \& Sutikno (2017).

Selain ceramah, BAZNAS Kepulauan Meranti melaui UPZ Rangsang Barat juga menggunakan metode atau cara diskusi dalam berdakwah zakat. Abdul Rauf, Ketua UPZ Rangsang barat, menuturkan bahwa: "Metode diskusi ini juga kami lakukan dalam sosialisasi zakat padi ini, karena metode ini kita bisa mengetahui apakah petani padi itu paham atau tidak tentang pelaksanaan zakat padi ini”. Hal ini juga sejalan yang disampaikan oleh Sunarto Ketua BAZNAS Kabupaten Kepulauan Meranti bahwa: "Metode diskusi ini sangat bagus dilaksanakan, karena kenapa? Agar petani padi $t u$ bisa lebih paham dan mengerti betul lah tentang pelaksanaan zakat padi ini”.

Penggunaan metode diskusi ini terkait dengan kelenturan cara ini dalam merespons hal-hal yang mungkin tidak diketahui oleh peserta. Abdul Rauf UPZ Rangsang Barat juga menambahkan bahwa:

"Metode diskusi ini memiliki kelebihan dari metode ceramah, karena kalau metode ceramah itu, terlalu monoton sehingga membuat petani padi jenuh atau bosan. Dan juga metode ini memberikan kesempatan kepada petani padi untuk bertanya langsung tentang materi yang tidak dipahaminya. 
Dalam pelaksanaanya, Sodikin Sekretaris UPZ Rangsang Barat menjelaskan bahwa:

"Metode diskusi dilaksanakan atas kesepakatan bersama antara pengurus UPZ dan petani padi biasanya dilaksanakan setelah salat Asar di masjid terdekat, selain itu juga metode diskusi ini dilaksanakan ketika wirid yasinan ibu-ibu setiap pekannya, kalau di Desa Segomeng, wirid Yasin ibuk-ibuk dilaksanakan pada hari jum'at jam 14.00.”

Metode ini sepertinya merupakan modernisasi dari cara atau metode ceramah yang memiliki kekurangan. Sunarto Ketua BAZNAS Kabupaten Kepulauan Meranti menjelaskan bahwa:

"Metode ini dipimpin pemateri yang memiliki pengetahuan yang luas tentang zakat padi, karena metode diskusi menuntut pemateri bisa menjawab semua pertanyaan dari petani padi. Dalam hal ini, metode diskusi dipimpin oleh ustaz Rauf yang sekaligus Ketua UPZ Rangsang Barat dan tidak menutup kemungkinan ustaz lainnya yang memiliki pengetahuan yang luas tentang pelaksanaan zakat padi”.

Namun demikian, hibriditas metode juga dimungkinkan sesuai situasi dan kondisi yang memungkinkan cara tersebut diperlukan. Abdul Rauf Ketua UPZ Rangsang Barat menambahkan:

"Sebelum diadakan metode diskusi ini, terlebih dahulu kami memberikan sedikit ceramah terkait materi yang disampaikan sekitar 10 menit lah, setelah itu dilanjutkan dengan tanya jawab, sedangkan kalau dilaksanakan ketika wirid Yasin ibuk-ibuk, metode diskusi ini dilaksanakan setelah pembacaan Yasin secara bersama-sama dan penyampaian ceramah oleh ustaz kemudian dilanjutkan sesi tanya jawab".

Dalam proses diskusi, biasanya banyak sekali pertanyaan-pertanyaan yang dilontarkan oleh petani padi, sebagaimana yang disampaikan oleh Abdul Rauf Ketua UPZ Rangsang Barat bahwa:

"Pertanyaan yang biasa ditanyakan adalah berapa batas diwajibkannya mengeluarkan zakat padi ini, kemudian kalau dah wajib zakat berapa pulak yang harus dikeluarkan, dan bagaimana kalau seandainya petani yang menanam padi sedangkan lahannya milik orang lain. Dan pertanyaan lainnya sekitar zakat pertanian" Barat:

Berikut ini adalah tabel dakwah zakat padi melalui diskusi di Kecamatan Rangsang

Table 5.2 Sosialisasi Zakat Padi melalui Diskusi

\begin{tabular}{clcccl}
\hline No & Hari/Tanggal & Jam & Tempat & Materi & \multicolumn{1}{c}{ Pemateri } \\
\hline 1 & Minggu/22 Juli & 14.00 & Masjid & Pelaksanaan & Abdul Rauf, \\
& 2018 (Wirid \\
Yasin Ibu-Ibu) & & Mekar Baru & zakat padi & $\begin{array}{l}\text { M.Pd.I (Ketua } \\
\text { UPZ Rangsang } \\
\text { Barat) }\end{array}$ \\
\hline 2 & & & & \\
& & & & & Kamis/2 \\
Agustus 2018 & 16.00 & Masjid Bina & Pelaksanaan & Khozin,MA \\
& & Maju & zakat padi & (Sekretaris \\
& (Kesepakatan & & & & BAZNAS \\
bersama) & & & & Meranti) \\
\hline 3 & Juma'at/21 & 14.00 & Masjid & Pelaksanaan & K. Rahmat \\
& September & & Desa & zakat padi & (Anggota UPZ \\
& 2018 (Wirid & & Segomeng & & Rangsang Barat) \\
& Yasin Ibu-Ibu) & & & & \\
\hline
\end{tabular}


Selain metode ceramah dan diskusi, cara door to door juga digunakan untuk meningkatkan pemahaman masyarakat muslim dalam membayar zakat padi. Berdasarkan wawancara dengan Abdul Rauf Ketua UPZ Rangsang Barat menuturkan, "Metode door to door ini juga kami laksanakan dalam sosialisasi zakat padi, kalau di istilahkan seperti jemput bola, di mana kami mengujungi petani padi yang memiliki lahan padi". Di waktu yang berbeda Sodikin Sekretaris UPZ Rangsang Barat juga menambahkan, "Metode ini memang kami laksanakan dalam sosialisasi zakat padi, yaitu dengan mengunjungi masyarakat yang bekerja sebagai petani padi dan menjelaskan pelaksanaan zakat padi."

UPZ Rangsang Barat melakukan metode door to door ini juga dengan cara mengunjungi tokoh masyarakat setempat, sebagaimana hasil wawancara dengan Muslim, Ketua Bidang Pengumpulan dan Pengembangan BAZNAS Kabupaten Kepulauan Meranti bahwa: "Kami juga mengunjungi tokoh masyarakat seperti pengurus masjid, pengurus kelompok tani padi, agar nantinya dapat saling bekerja sama dalam upaya mensosialisasikan pelaksanaan zakat padi ini".

Metode ini dinggap efektif bagi sebagian pengurus BAZNAS karena secara tradisional model pendekatan ini meningkatkan hubungan dan keterikatan sosial kedua belah pihak. Sunarto, Ketua BAZNAS Kabupaten Kepulauan Meranti menyatakan:

"Metode ini sangat efektif dilaksanakan dalam upaya untuk meningkatkan pengumpulan zakat padi, namun dari pada itu juga, metode ini menuntut pengurus BAZNAS lebih aktif dalam mencari calon-calon muzaki zakat padi ini, dengan cara mencari informasi terlebih dahulu siapa saja masyarakat yang memiliki lahan padi dan bekerja sebagai petani padi."

Dalam pelaksanaannya, sebagaimana hasil wawancara dengan Sodikin Sekretaris UPZ Rangsang Barat bahwa, "Waktu pelaksanaan metode ini kondisional, untuk tempatnya kadang di rumah petani padi tersebut atau di pondok kebunnya, dan juga bisa di mana ketika pengurus BAZNAS berjumpa dengan petani padi”.

Untuk lebih jelasnya penulis lampirkan tabel pelaksanaan zakat padi melalui door to door di Kecamatan Rangsang Barat:

Table 5.3 Sosialisasi Zakat Padi melalui Door To Door

\begin{tabular}{|c|c|c|c|c|c|}
\hline No & Hari/Tanggal & Jam & Tempat & Materi & Pemateri \\
\hline 1 & $\begin{array}{l}\text { Kamis/4 Januari } \\
2018 \\
\text { (Menjumpai } \\
\text { Ketua Masjid) }\end{array}$ & 20.00 & $\begin{array}{c}\text { Masjid } \\
\text { Mekar Baru }\end{array}$ & $\begin{array}{l}\text { Pelaksanaan } \\
\text { zakat padi }\end{array}$ & $\begin{array}{l}\text { Abdul Rauf, M.Pd.I } \\
\text { (Ketua UPZ } \\
\text { Rangsang Barat) }\end{array}$ \\
\hline 2 & $\begin{array}{l}\text { Rabu/17 Januari } \\
2018 \\
\text { (Menjumpai } \\
\text { Ketua } \\
\text { Kelompok Tani) }\end{array}$ & 10.00 & $\begin{array}{l}\text { Kediaman } \\
\text { Kelompok } \\
\text { Tani }\end{array}$ & $\begin{array}{l}\text { Pelaksanaan } \\
\text { zakat padi }\end{array}$ & $\begin{array}{l}\text { Sodikin (Sekretaris } \\
\text { UPZ Rangsang } \\
\text { Barat) }\end{array}$ \\
\hline 3 & $\begin{array}{l}\text { Senin/12 } \\
\text { Februari } 2018 \\
\text { (Menjumpai } \\
\text { Petani Padi) } \\
\end{array}$ & 16.00 & $\begin{array}{c}\text { Pondok } \\
\text { Petani Padi }\end{array}$ & $\begin{array}{l}\text { Pelaksanaan } \\
\text { zakat padi }\end{array}$ & $\begin{array}{l}\text { Muslim, S.Pd. I (Staf } \\
\text { Pengumpulan } \\
\text { BAZNAS Meranti) }\end{array}$ \\
\hline
\end{tabular}

Komunikasi tatap muka seperti door to door di atas dipergunakan dengan tujuan untuk mendapatkan efek perubahan tingkah laku (behavior change) dari komunikan. Hal tersebut dimungkinkan karena dalam berkomunikasi akan terjadinya umpan balik langsung (Wardani: 
2018). Menurutnya, sebagaimana mengutip Dedy Mulyana, dengan berinteraksi dan bertemu langsung, komunikator bisa mengetahui respons dan tanggapan dari komunikan terhadap pesan yang disampaikan. Selanjutnya, dengan bertemu langsung, seorang komunikator bisa membangun hubungan emosional dengan komunikan. Hal ini berguna untuk mengundang simpati dan keinginan komunikan untuk berzakat (Effendy : 2017).

\section{Integrasi Instrumen Modern dan Dakwah Zakat}

Dalam bagian ini akan dijelaskan bagaimana proyek dakwah tidak pernah luput dari elemen modernitas. Merespons tuntunan modernitas, sosialisasi atau dakwah zakat yang dilakukan menggunakan media-media modern. Berdasarkan wawancara dengan Sunarto Ketua BAZNAS Kabupaten Kepulauan Meranti menuturkan,

"Selain melakukan metode sosialisasi yang sifatnya tradisional seperti ceramah dan sejenisnya, BAZNAS Kabupaten Kepulauan Meranti juga memanfaatkan media elektronik seperti radio. Adapun radio yang kami ajak kerja sama dalam sosialisasi zakat ini adalah radio SMKart 88,4 FM Selat Panjang"

Hal ini juga sejalan dengan yang disampaikan oleh Mustafa Wakil Ketua I Pengumpulan dan Pengembangan BAZNAS Kabupaten Kepulauan Meranti, "BAZNAS Kabupaten Kepulauan Meranti telah lama menggunakan radio sebagai media sosialisasi zakat, yaitu bekerja sama dengan Radio SMKart 88,4 FM Selat Panjang”.

Adapun alasan utama penggunaan radio sebagai sarana atau medium dakwah zakat sebagaimana dikatakan oleh Muslim, Ketua Staf Pengumpulan dan Pengembangan BAZNAS, "Pemanfaatan radio sebagai sosialisasi zakat di BAZNAS Kabupaten Kepulauan Meranti bekerja sama dengan radio SMKart 88,4 FM Selat Panjang, radio ini kami pilih karena memiliki jangkauan yang sangat luas, sampai ke 6 desa yang memiliki lahan padi”.

Sosialisasi zakat melalui radio dianggap memiliki kelebihan dalam aspek sistem, prosedur, kemudahan, dan tata cara. Tidak heran jika BAZNAS Kepulauan Meranti kemudian melakukan kerja sama dengan radio terkait. Sunarto Ketua BAZNAS Kabupaten Kepulauan Meranti menuturkan, "Sistem kerjasama yang dilakukan BAZNAS Kabupaten Kepulauan Meranti dengan Radio SMKart 88,4 FM Selat Panjang adalah dalam bentuk ceramah dan tanya jawab serta pemutaran iklan layanan masyarakat tentang sosialisasi zakat".

Muslim, Ketua Bidang Pengumpulan dan Pengembangan BAZNAS Kabupaten Kepulauan Meranti menjelaskan bahwa:

"Ceramah dan tanya jawab ini dilaksanakan sebulan sekali, biasanya pekan pertama hari kamis atau bisa juga di hari yang lain, sesuai kesepakatan dengan pemateri. Waktu pelaksanaanya pukul 16.30-17.30 WIB. 15 menit itu untuk ceramah dan selebihnya 45 menit itu tanya jawabnya dengan pendengar melalui via telepon, tema ceramah setiap bulannya berubah-ubah, sedangkan untuk tanya jawabnya boleh keluar dari tema yang ditentukan, sedangkan iklan layanan masyarakat itu berisikan penjelasan tentang program BAZNAS, jenis-jenis zakat, tata cara untuk berzakat serta himbauan untuk berzakat ke BAZNAS Kabupaten Kepulauan Meranti, iklan ini durasinya sekitar 1 menit, dan diputar setiap hari”.

Pelaksanaan sosialisasi zakat di radio ini juga dibenarkan salah seorang petani padi yang ada di Desa Anak Setatah, Abdul Hamid, yang menuturkan, "Kami mengetahui tentang nisab zakat padi dari iklan yang ada di radio SMK Selat Panjang, yang menjelaskan kalau penghasilan padi kita sampai 55 TIM itu sudah wajib zakat”.

Untuk lebih jelasnya, berikut adalah tabel pelaksanaan zakat padi melalui dialog interaktif di radio SMKArt 88.4 FM Selat Panjang: 
Table 5.4 Sosialisasi Zakat Padi melalui Radio SMKArt

\begin{tabular}{|c|c|c|c|c|c|}
\hline No & Hari/Tanggal & Jam & Tempat & Materi & Pemateri \\
\hline 1 & $\begin{array}{l}\text { Kamis/8 Maret } \\
2018\end{array}$ & 16.30 & $\begin{array}{l}\text { Studio } \\
\text { radio } \\
\text { SMKArt }\end{array}$ & $\begin{array}{l}\text { Pelaksanaan } \\
\text { zakat padi }\end{array}$ & $\begin{array}{l}\text { Khozin,MA } \\
\text { (Sekretaris } \\
\text { BAZNAS } \\
\text { Meranti) }\end{array}$ \\
\hline 2 & Jumat/6 April 2018 & 16.30 & $\begin{array}{l}\text { Studio } \\
\text { radio } \\
\text { SMKArt }\end{array}$ & $\begin{array}{l}\text { Bayarlah zakat } \\
\text { ke BAZNAS }\end{array}$ & $\begin{array}{l}\text { Sunarto, S.Ag } \\
\text { (Ketua } \\
\text { BAZNAS } \\
\text { Meranti) } \\
\end{array}$ \\
\hline 3 & Rabu/2 Mei 2018 & 16.30 & $\begin{array}{l}\text { Studio } \\
\text { radio } \\
\text { SMKArt }\end{array}$ & $\begin{array}{l}\text { Zakat untuk } \\
\text { Kemakmuran } \\
\text { Umat }\end{array}$ & $\begin{array}{l}\text { Mustafa, S.Ag, } \\
\text { MM (Wakil } \\
\text { ketua I } \\
\text { BAZNAS } \\
\text { Meranti) }\end{array}$ \\
\hline
\end{tabular}

Penggunaaan media radio dalam dakwah zakat padi memungkinkan efektivitas kegiatan tersebut. Hal ini karena media modern ini, menurut Samsul Munir Amin (2009: 270271) sebagai media komunikasi, ia memiliki daya langsung, memiliki daya tembus, dan memiliki daya tarik. Di samping itu, radio bisa memberikan penyegaran informasi dan hiburan masyarakat. Media ini juga mudah dijangkau oleh masyarakat luas karena harganya relatif murah dan cara penggunaanya yang gampang (Ma'arif, 2010: 163).

Selain radio, BAZNAS Kepulauan Meranti juga menggunakan media modern lain seperti media cetak. Media cetak yang dimaksud sebenarnya masih dalam konteks tradisional. Sunarto Ketua BAZNAS Kabupaten Kepulauan Meranti menuturkan, "BAZNAS Kabupaten Kepulauan Meranti juga menggunakan media cetak salah satunya spanduk sebagai metode sosialisasi zakat padi”.

Muslim, Ketua Bidang pengumpulan dan pengembangan BAZNAS Kabupaten Kepulauan Meranti menjelaskan,

"Sosialisasi zakat melalui spanduk itu kami laksanakan dengan memasang spanduk di tempat-tempat strategis, seperti di persimpangan jalan, masjid, dan di lahan pertanian padi. Spanduk ini berisikan tentang penjelasan tentang nisab, haul, dan kadar zakat padi serta himbauan untuk berzakat ke BAZNAS Kabupaten Kepulauan Meranti."

Spanduk digunakan sebagai media dakwah zakat padi memungkinkan setiap petani dengan mudah mengetahui informasi tentang zakat padi. Salah seorang petani padi yang ada di Desa Segomeng, Farida, menuturkan bahwa: "Spanduk yang berisikan tata cara pelaksanaan zakat padi ada di pasang di desa kami, biasanya di persimpangan jalan dan juga di lahan sawah padi kami."

Selain itu juga BAZNAS Kabupaten Kepulauan Meranti juga menggunakan media cetak lainnya yaitu brosur. Muslim, Ketua Bidang pengumpulan dan pengembangan BAZNAS Kabupaten Kepulauan Meranti menjelaskan,

"Brosur juga menjadi salah satu cara BAZNAS Kabupaten Kepulauan Meranti dalam mensosialisasikan zakat padi, brosur tersebut berisikan penjelasan tentang nisab, haul, dan kadar zakat padi yang telah ditetapkan oleh pengurus BAZNAS Kabupaten Kepulauan Meranti dengan menyesuaikan tata cara pelaksanaan zakat padi masyarakat setempat yang menggunakan hitungan TIM." 
Brosur disebarkan kepada para petani untuk dibaca dan dipahami. Sodikin, Sekretaris UPZ Rangsang Barat menambahkan, "Brosur tersebut kami perbanyak dan bagikan ke petani padi serta ditempel di tempat-tempat strategis seperti masjid, kedai harian, dan tempat penggilingan padi."

\section{Simpulan}

Pasca Orde Baru, lembaga-lembaga zakat tumbuh subur sebagai akibat dari meluasnya kesadaran masyarakat muslim dalam konteks marginalisasi umat dalam percaturan atau kompetisi perebutan sumber-sumber ekonomi. Selama ini, sebagaimana dikemukakan oleh Hadiz (2018), isu marginalisasi umat begitu kuat dalam penguatan simbol-simbol Islam di ranah publik (baca: populisme Islam). Namun, faktanya sebagaimana ditemukan dalam artikel ini, isu ketertinggalan umat masih belum sempurna dalam memperkuat kesadaran masyarakat muslim dalam membayar zakat padi. Hal ini terlihat dari bagaimana upaya BAZNAS mengintegrasikan manajemen dan instrumen modern dalam mensosialisasikan zakat padi dalam komunitas muslim. Dibatasi oleh kekurangan manajemen modern, BAZNAS sebagai lembaga zakat terus berupaya memperkuat dan mendorong kesadaran masyarakat muslim berzakat sebagai simbol kesalehan Artikel ini juga menunjukan bahwa lembaga-lembaga zakat yang semi-modern, seperti BAZNAS Kepulauan Meranti melakukan negosiasi yang kompleks dan rumit terkait kesadaran religius dan problem modernitas. Lembaga-lembaga ini seperti di daerah lain di Indonesia sering menghadapi kegagapan teknologi dan manejemen modern di tengah spirit religiusitas yang kuat.

Temuan artikel ini menunjukkan bagaimana menyebarkan pemahaman kewajiban berzakat sebagai proyek yang tak pernah selesai sebab nilai-nilai religiusitas acap kali membutuhkan instrumen modern. Ruang kosong yang dibutuhkan lembaga-lembaga religius ini adalah memperkuat instrumen modern dan implementasi manajemen modern dalam lembaga-lembaga tersebut. Persoalannya dengan demikian bukan meningkatkan paham keagamaan mereka yang sudah mapan melalui ceramah agama ataupun aktivitas keagamaan yang lain.

Dalam artikel ini ditemukan bahwa BAZNAS Kepulauan Meranti mengintegrasikan cara-cara modern dalam aktivitas dakwah zakat padi yang dilakukan. Hal ini terlihat dari caracara yang mereka gunakan melalui metode diskusi, penggunaan media radio, serta penggunaan media cetak seperti brosur dan spanduk. Keberhasilan cara yang dilakukan tergantung sejauh mana keberhasilan mereka dalam menggunakan manajemen dan instrumen modern ini di masa-masa yang akan datang, bukan keberhasilan mereka dalam meningkatkan kesadaran religiusitas mereka.

\section{Referensi}

Ali, Mohammad Daud. (1988). Sistem Ekonomi Islam: Zakat dan Wakaf. Jakarta: UI Press. Amin, Samsul Munir. (2009). Ilmu Dakwah. Jakarta: Hamzah.

Aripudin, Acep. (2011). Pengembangan Metode Dakwah: Respon Da’i Terhadap Dinamika Kehidupan. Jakarta: Rajawali Press.

Effendy, Onong Uchjana. (2017). Ilmu Komunikasi Teori dan Praktek. Bandung: PT Remaja Rosdakarya.

Farida, Anik., et al. (2016). Pemberdayaan Potensi Zakat di Jawa Barat: Studi pada Lazismu Masjid Mujahidin Bandung dan BAZDA Jawa Barat. Jakarta: Kementerian Agama.

Fathurrohman, Pupuh \& Sutikno, M. Sobry. (2017). Strategi Belajar Mengajar: Strategi Mewujudkan Pembelajaran Bermakna Melalui Pemahaman Konsep Umu dan islami. Bandung: PT Refika Aditama. 
Hadiz, Vedi R. (2018). Populisme Islam di Indonesia dan Timur Tengah. Jakarta: LP3ES dan Lab Sosiologi Universitas Indonesia.

Hasan, Muhammad. (2011), Manajemen Zakat Model Pengelolaan yang Efektif. Yogyakarta: Idea Press Yogyakarta.

Hassan, Riaz. (2006). Keragaman Iman: Studi Komparatif Masyarakat Muslim, Jakarta: PT Rajagrafindo Persada.

Hidayah, Rahmi. (2015). Strategi Komunikasi Lembaga Amil Zakat (LAZ) Swadaya Ummah dalam Meningkatkan Jumlah Muzakki di Pekanbaru. Jurnal Ilmu Komunikasi FISIP UNRI, 2(2).

Ilahi, Wahyu. (2010). Komunikasi Dakwah. Bandung: PT Remaja Rosdakarya.

Isma'il. (2016). Pemberdayaan Ekonomi Keagamaan Melalui BAZNAS Kota Cilegon dalam Tim Penulis Balai Litbang Agama Jakarta, Zakat sebagai Filantropi Pemberdaya Umat. Jakarta: Kementerian Agama.

Marpuah. (2016). Pengelolaan Zakat di BAZNAS Provinsi Sumatera Barat dalam Tim Penulis Balai Litbang Agama Jakarta, Zakat sebagai Filantropi Pemberdaya Umat, Jakarta: Kementerian Agama.

Maryatin. (2014). Efektifitas Metode Ceramah dalam Penyampaian Dakwah Islam, Jurnal Ilmu Dakwah, 34 (1).

Ma'arif, Bambang Saiful. (2010). Komunikasi Dakwah Paradigma untuk Aksi. Bandung: Simbiosa Rekatama Media.

Murti, Nurizka Listyo. (2017). Strategi Marketing Door To Door dalam Meningkatkan Jumlah Aggota di BMT Al-Hikmah Cabang Gunungpati Sekaran, Skripsi Program D3 Perbankan Syariah Universitas Islam Negeri Walisongo: Semarang.

Salim, Delmus Puneri. (2015). The Transnational and the Local in the Politics of Islam: The Case of West Sumatra, Indonesia. London: Springer.

Sugiyono, (2015). Memahami Penelitian Kualitatif. Bandung: Alfabeta.

Wahab, Abdul Aziz. (2012). Metode dan Model-Model Mengajar. Bandung: Alfabeta.

Wardani, Rama Wijaya Kesuma. (2018). Manajemen Komunikasi Badan Amil Zakat Nasional (BAZNAS) Provinsi Jawa Barat. Jurnal Peradaban dan Pemikiran Islam, $1(2)$.

Yusuf. (2002). Pengunaan Metode yang Efektif dalam Pembelajaran. Jakarta: Depdiknas.

\section{Dokumentasi Badan Amil Zakat Nasional Kabupaten Kepulauan Meranti}

Hasil wawancara dengan Ketua BAZNAS Kabupaten Kepulauan Meranti pada tanggal 7 Desember 2018, pukul 14.00.

Hasil wawancara dengan Sekretaris UPZ Rangsang Barat pada tanggal 10 Desember 2018, pukul 08.30.

Hasil wawancara dengan Ketua BAZNAS Kabupaten Kepulauan Meranti pada tanggal 7 Desember 2018, pukul 14.05

Hasil wawancara dengan Ketua BAZNAS Kabupaten Kepulauan Meranti pada tanggal 7 Desember 2018, pukul 14.10

Hasil wawancara dengan Ketua UPZ Rangsang Barat pada tanggal 10 Desember 2018, pukul 09.00 .

Hasil wawancara dengan Sekretaris UPZ Rangsang Barat pada tanggal 10 Desember 2018, pukul 08.00.

asil wawancara dengan Ketua BAZNAS Kabupaten Kepulauan Meranti pada tanggal 7 Desember 2018, pukul 14.15. 
Hasil wawancara dengan Ketua UPZ Rangsang Barat pada tanggal 10 Desember 2018, pukul 09.05 .

Hasil wawancara dengan Sekretaris UPZ Rangsang Barat pada tanggal 10 Desember 2018, pukul 08.05

Hasil wawancara dengan Ketua Kelompok Tani Nelayan Andalan Desa Mekar Baru pada tanggal 10 Desember 2018, pukul 10.05.

Hasil wawancara dengan Ketua UPZ Rangsang Barat pada tanggal 10 Desember 2018, pukul 09.10 .

Hasil wawancara dengan Sekretaris UPZ Rangsang Barat pada tanggal 10 Desember 2018, pukul 08.10.

Hasil wawancara dengan Ketua UPZ Rangsang Barat pada tanggal 10 Desember 2018, pukul 09.15 .

Hasil wawancara dengan Ketua UPZ Rangsang Barat pada tanggal 10 Desember 2018, pukul 09.18 .

Hasil wawancara dengan Sekretaris UPZ Rangsang Barat pada tanggal 10 Desember 2018, pukul 08.15.

Hasil wawancara dengan Ketua Bidang pengumpulan dan pengembangan BAZNAS Kabupaten Kepulauan Meranti pada tanggal 10 Desember 2018, pukul 11.00.

Hasil wawancara dengan Ketua UPZ Rangsang Barat pada tanggal 10 Desember 2018, pukul 09.20 .

Hasil wawancara dengan Ketua BAZNAS Kabupaten Kepulauan Meranti pada tanggal 7 Desember 2018, pukul 14.17.

Hasil wawancara dengan KetuaUPZ Rangsang Barat pada tanggal 10 Desember 2018, pukul 09.20 .

Hasil wawancara dengan Sekretaris UPZ Rangsang Barat pada tanggal 10 Desember 2018, pukul 08.20.

Hasil wawancara dengan Ketua BAZNAS Kabupaten Kepulauan Meranti pada tanggal 7 Desember 2018, pukul 14.20.

Hasil wawancara dengan KetuaUPZ Rangsang Barat pada tanggal 10 Desember 2018, pukul 09.23 .

Hasil wawancara dengan Sekretaris UPZ Rangsang Barat pada tanggal 10 Desember 2018, pukul 08.28.

Hasil wawancara denganK etua Bidang pengumpulan dan pengembangan BAZNAS Kabupaten Kepulauan Meranti pada tanggal 10 Desember 2018, pukul 11.05

Hasil wawancara dengan Ketua BAZNAS Kabupaten Kepulauan Meranti pada tanggal 7 Desember 2018, pukul 14.25.

Hasil wawancara dengan Sekretaris UPZ Rangsang Barat pada tanggal 10 Desember 2018, pukul 08.30.

Hasil wawancara dengan Ketua BAZNAS Kabupaten Kepulauan Meranti pada tanggal 7 Desember 2018, pukul 14.28.

Hasil wawancara dengan Wakil Ketua I pengumpulan dan pengembangan BAZNAS Kabupaten Kepulauan Meranti pada tanggal 11 Desember 2018, pukul 10.30.

Hasil wawancara dengan Ketua Bidang pengumpulan dan pengembangan BAZNAS Kabupaten Kepulauan Meranti pada tanggal 10 Desember 2018, pukul 11.10.

Hasil wawancara dengan Ketua BAZNAS Kabupaten Kepulauan Meranti pada tanggal 7 Desember 2018, pukul 14.30.

Hasil wawancara dengan Ketua Bidang pengumpulan dan pengembangan BAZNAS Kabupaten Kepulauan Meranti pada tanggal 10 Desember 2018, pukul 11.10. 
Hasil wawancara dengan Ketua BAZNAS Kabupaten Kepulauan Meranti pada tanggal 7 Desember 2018, pukul 14.30.

Hasil wawancara dengan petani padi Desa Anak Setatah pada tanggal 11 Desember 2018, pukul 16.00 .

Hasil wawancara dengan Ketua BAZNAS Kabupaten Kepulauan Meranti pada tanggal 7 Desember 2018, pukul 14.32.

Hasil wawancara dengan Wakil Ketua I pengumpulan dan pengembangan BAZNAS Kabupaten Kepulauan Meranti pada tanggal 11 Desember 2018, pukul 10.33.

Hasil wawancara dengan Ketua Bidang pengumpulan dan pengembangan BAZNAS Kabupaten Kepulauan Meranti pada tanggal 10 Desember 2018, pukul 11.12.

Hasil wawancara dengan petani padi Desa Segomeng pada tanggal 12 Desember 2018, pukul 16.00 .

Hasil wawancara dengan Ketua BAZNAS Kabupaten Kepulauan Meranti pada tanggal 7 Desember 2018, pukul 14.35.

Hasil wawancara dengan Ketua Bidang pengumpulan dan pengembangan BAZNAS Kabupaten Kepulauan Meranti pada tanggal 10 Desember 2018, pukul 11.15.

Hasil wawancara dengan Sekretaris UPZ Rangsang Barat pada tanggal 10 Desember 2018, pukul 08.35. 